\title{
EXPLORING THE EFFECT OF ULTRAFILTRATION/DIAFILTRATION PROCESSING CONDITIONS ON THE LACTOFERRIN AND IMMUNOGLOBULIN G CONTENT OF FETA WHEY PROTEIN CONCENTRATES
}

\author{
EFSTATHIA TSAKALI ${ }^{1}$, KONSTANTINOS PETROTOS ${ }^{2}$, ANGELA G. D'ALESSANDRO ${ }^{1}$, CHRISTOS MANTAS ${ }^{2}$, \\ IOANNIS TRIPOLITSIOTIS ${ }^{2}$, PANAGIOTIS GOULAS ${ }^{3}$, ARHONTOULA CHATZILAZAROU ${ }^{4}$ and \\ JAN F. VAN IMPE 5,6 \\ 1'Department of Scienze Agro-Ambientali e Territoriali, Università degli Studi di Bari, Bari, Italy \\ Departments of ${ }^{2}$ Biosystems and ${ }^{3}$ Animal Production, Technological Educational Institute of Larissa, Larisa, Greece \\ ${ }^{4}$ Department of Oenology and Beverage Technology, Technological Educational Institute of Athens, Athens, Greece \\ ${ }^{5}$ Chemical Engineering Department (BioTeC \& OPTEC), Katholieke Universiteit Leuven, W. de Croylaan 46, PB 2423, 3001 Leuven, Belgium
}

\author{
${ }^{6}$ Corresponding author. \\ TEL: 321-632-1466; \\ FAX: 321-632-2991; \\ EMAIL: jan.vanimpe@cit.kuleuven.be
}

Received for Publication June 2, 2014

Accepted for Publication October 10, 2014

doi:10.1111/jppe.12167

\begin{abstract}
In this paper, the production of powder enriched in lactoferrin (Lf) and immunoglobulin $\mathrm{G}(\mathrm{IgG})$ from untreated feta cheese whey is studied. More specifically, the influence of transmembrane pressure $(\Delta p)$ and temperature on flux and separation ability during ultrafiltration combined with continuous diafiltration is investigated. Two different types of membranes were used, a spiral polyvinylidene fluoride (PVDF) (molecular weight cut-off [MWCO $\sim 75 \mathrm{kDa}$ ) and a set of 18 cylindrical PVDF membranes (MWCO $\sim 100 \mathrm{kDa}$ ). For the production of the whey powder, two drying methods were compared: spray and freeze drying. All combinations lead to powder with high total protein content and with a notable content in these two bioactive proteins. However, cylindrical membranes (at a temperature of $20^{\circ} \mathrm{C}$ and a transmembrane pressure of 4 bar) in combination with freeze drying resulted in the highest yield from whey into Lf and IgG and excellent sensory characteristics.
\end{abstract}

\section{PRACTICAL APPLICATIONS}

Whey powder enriched in the multifunctional proteins lactoferrin and immunoglobulin $G$ have very large potential both as nutrition additives and for pharmaceutical purposes. The systematic study of the parameters affecting all unit operations involved leads to the most efficient and cheapest production. In order to achieve this, the methodology was kept as simple and low cost as possible. This way, a strong tool could be created for the utilization of the cheese-making by-product whey, which still causes large environmental problems.

\section{INTRODUCTION}

\section{Whey}

Whey as a by-product of cheesing making has been problematic to dispose of for several reasons. Probably, the most important is its high $\mathrm{BOD}_{5}$ (Biochemical Oxygen Demand, i.e., the amount of $\mathrm{O}_{2}$ in $\mathrm{mg}$, needed for the biological oxidization of the organic load per litre of whey, in five days time), which is about $35,000-55,000 \mathrm{mg} \mathrm{O}_{2} / \mathrm{L}$. As more than $145,000,000$ tons of whey is produced worldwide annually, the development of novel methods for whey valorization is becoming increasingly important. Over the last years, several studies were carried out concerning the importance of whey's nutritional value and the properties of its ingredients. Whey protein, consisting of individual proteins and peptides, is the most interesting ingredient to explore because of its great nutritional value. Protein that originated 
from whey, compared with other foods, is rich in essential amino acids and has more than $20 \%(\mathrm{w} / \mathrm{w})$ of the branched chain amino acids (leucine, isoleucine and valine). These amino acids are thought to be metabolic regulators in protein and glucose homeostasis and in lipid metabolism, thus they can play a role in weight control. Apart from these compounds, whey protein is also rich in sulfur amino acids (methionine, cysteine), which participate as antioxidants, as precursors to the potent intracellular antioxidant glutathione, and in one-carbon metabolism. In addition to its high nutritional value, it has also many other notable functions such as prevention of cancer (Gill and Cross 2000), increment of glutathione levels (Parodi 1998), antimicrobial activities (Clare et al. 2003) and increment of satiety response (Hall et al. 2003).

Over the last few decades, dairy companies have applied different technologies to process cheese whey, resulting in its separation into its principal components, comprising fractions enriched in proteins, lactose and minerals. These technologies generally consist of crystallization, membrane and chromatographic processes.

\section{Membrane Technology}

Membrane systems are used extensively throughout the dairy industry to control protein, fat and lactose contents of a variety of products. Membrane processes have been successful because they can be effectively and economically implemented at a large scale, which is required for most dairy applications (Zydney 1998). These techniques are basically filtration processes, exploiting membranes as filtration media in order to separate solid components from the liquid phase. These processes have been used for whey treatment since the late 1970s and early 1980s using cellulose acetate membranes in the early stages of development, which were later replaced by more resistant and durable membranes made of polysulfones or polyethersulfones (Garcia-Garibay et al. 2008). Pressure-driven membrane techniques used to produce whey protein concentrates and isolates are reverse osmosis, ultrafiltration (UF), microfiltration and nanofiltration. Electrically driven membrane processes used are electrodialysis and electrodeionization (Foegeding and Luck 2002).

The principal aim of whey UF is to concentrate the native or predenatured whey proteins in order to obtain a whey protein powder with variable protein content and reduced lactose and ash contents (Marshall 1982; Da Costa et al. 1993; Huffman 1996; Atra et al. 2005). UF uses polymeric or ceramic membranes (which are fully retentive to whey proteins) to remove lactose and minerals, yielding a retentate stream that can be further processed by evaporation and drying. The net result is a whey protein concentrate of about $60 \%(\mathrm{w} / \mathrm{w})$ protein. The lactose and mineral contents in whey can be further reduced using a subsequent diafiltration (DF) step in which deionized water is continuously added to the retentate, whereas lactose and minerals are simultaneously removed in the filtrate. This combined UF-DF yields a highly concentrated (and thus valuable) retentate of about 85\% (w/w) protein (Zydney 1998).

In the last decade, whey processors have somewhat been a victim of their own success. The increasing volumes of edible lactose and whey protein concentrates flooding into the market have resulted in a downward trend in relative prices. Converting these semi-commodity products into high added-value products is an important challenge for today's industry.

Although membranes have been extensively used for the production of powder with rich protein content (up to $85 \%)$, the attempts to fractionate whey protein components with just membrane technology have not been so successful. Scott and Lucas (1989) developed a process for the preparation of purified immunoglobulins (Igs) from whey protein concentrate using a 100,000 molecular weight cut-off (MWCO) membrane. It allowed permeation of $\beta$-lactoglobulin $(\beta$-Lg), $\alpha$-lactalbumin $(\alpha$-La) and bovine serum albumin while retaining the Igs. However, the resulting retentate product only contained $10 \%(\mathrm{w} / \mathrm{w})$ Igs due to the poor resolution of the membrane. Similar results were obtained by Bottomley (1993) using a Romicon PM500 (500,000 MWCO) membrane, with an Igs concentration in the retentate of around $12 \%$. Further purification of the Igs required the use of a separate anion exchange system. Chen and Wang (1991) used affinity ligands in free solution to drastically increase the retention of immunoglobulin (using protein G) or lactoferrin (Lf) (using heparin sepharose), allowing these proteins to be effectively separated from the remaining whey proteins using microfiltration membranes. Protein yields and purities were acceptable, although it is doubtful that this type of affinity ligand system could be used economically for commercial whey fractionation.

\section{Feta Cheese}

Feta is a popular protected designation of origin cheese produced in specific parts of Greece from ovine or a mix of ovine and caprice milk. The annual production of feta in Greece is estimated at 95,400 tons (in 2012), leading to the production of 244,000-366,000 tons of sweet whey. Whey's composition and sensory characteristics vary depending on the kind of whey (acid or sweet), the source of milk (bovine, caprice, ovine milk, etc.) and the feed of the animal which produced the milk, the cheese processing method used, the time of the year and the lactation stage.

The main material for feta cheese production, ovine milk (at least $70 \%$ of total milk used), has a total whey protein concentration of $17 \mathrm{~g} / \mathrm{L}$ (Vincenzetti et al. 2008), which 
equals to almost three times the total whey protein of cow's milk (which is $6.3 \mathrm{~g} / \mathrm{L}$ ) (De Wit 1998). Goat milk, which can also be used (maximum $30 \%$ for feta cheese), has a whey protein content of $0.7 \mathrm{~g} / \mathrm{L}$. Larger amounts of whey protein have been reported in feta cheese whey when compared to bovine cheese whey. In particular, Moatsou et al. (2003) demonstrated that feta cheese whey protein concentrate had a much higher $\beta$-Lg and higher $\alpha$-La percentage than those reported for bovine whey protein concentrates (Morr 1985; Kinghorn etal. 1995; De Wit 1998; Holt et al. 1999; Elgar et al. 2000). Also, Tsakali et al. (2014) obtained $272 \pm 24 \mu \mathrm{g} / \mathrm{mL}$ as the average amount of Lf in feta cheese whey, whereas in bovine cheese whey, $100 \mu \mathrm{g} / \mathrm{mL}$ has been found (Plate et al., 2006).

\begin{abstract}
Aim
The aim of this paper was to explore the utilization of feta cheese whey for the production of whey powder with an increased content of two minor bioactive proteins, Lf and immunoglobulin G (IgG), using membrane technology. The selected technique was UF: it has been extensively used in dairy industry mostly because it can process large amounts of raw material and it can be combined with DF in order to increase selectivity. Therefore, other separation steps or techniques that have been reported to increase selectivity were not used. It was important that the whole process would be kept as simple as possible in order to investigate the easiest possible way to produce a valuable product from feta cheese whey, which is abundantly available but still underexploited.
\end{abstract}

\section{MATERIALS AND METHODS}

\section{Whey}

Whey from feta cheese making was obtained from the area of Larissa (Greece) on a daily basis. No pretreatment was applied.

\section{UF/DF Equipment}

The UF/DF process was implemented at pilot scale unit (Fig. 1), including a 50-L inox tank equipped with a serpentine heat exchanger, a membrane module, a set of membranes and two pumps with manometers. The first pump, which was used as an auxiliary pump for vibration minimization, was a centrifugal unit of $0.5 \mathrm{HP}(373 \mathrm{~W})$ and with a capacity of $26 \mathrm{~L} / \mathrm{min}$. The main pump for pressure control was a piston pump with three pistons and a bypass valve for blast.

Two membrane systems were tested. The first one was a set of 18 polyvinylidene fluoride (PVDF) membranes with an MWCO of $100 \mathrm{kDa}$ placed on a B1 single entry, parallel flow module (length $1.2 \mathrm{~m}$, diameter $100 \mathrm{~mm}$ and total membranes area $0.88 \mathrm{~m}^{2}$ ) (ITT PCI Membranes Ltd., Basingstoke, UK). The second one was a spiral PVDF membrane with an MWCO of $75 \mathrm{kDa}$, mounted on an EHS25NT-1435-200 module made of stainless steel (length $0.3556 \mathrm{~m}$, diameter $635 \mathrm{~mm}$, membrane area $0.5574 \mathrm{~m}^{2}$, plastic spacer of $31 \mu \mathrm{m}$ width) (Sepro Membranes Inc., Oceanside, California).

\section{Drying Equipment}

Two dryers were used, a BÜCHI mini spray dryer B290: BÜCHI Labortechnik AG, Flawil, Switzerland ScanVac Cool Safe 110 TM freeze dryer: LaboGene ApS, Lynge, Denmark. The level of drying was set according to the desired water activity $\left(a_{\mathrm{w}}\right)$ of the final powder, which should be at most 0.24 .

\section{Analytical Methods}

The composition of the produced powder was determined by analysis of the following parameters: total protein, Lf and IgG content, fat, lactose and total sugar, moisture and mineral content (ash).

Kjeldahl method was carried out for the determination of total protein content (International Dairy Federation 1964a; IDF 25:1964), whereas a reversed phase high-performance liquid chromatography method was used for the determination of Lf (Tsakali et al. 2014). For the analysis of IgG, a VWR Hitachi module with a diode array detector L-2455 Elite La Chrom was used. The column was a Zorbax SB 300C8, $4.6 \times 150 \mathrm{~mm}, 5-\mu \mathrm{m}$ particle size (Agilent, Santa Clara, CA). Mobile phase A consisted of water/acetonitrile/ trifluoroacetic acid (95:5:0.1) and mobile phase B consisted of water/acetonitrile/trifluoroacetic acid (5:95:0.1). Linear gradient within a run time of $30 \mathrm{~min}$ and combination of flow rates from 1.0 to $1.5 \mathrm{~mL} / \mathrm{min}$ were used. The column temperature was set at $50 \mathrm{C}$, whereas the injection volume was $10 \mu \mathrm{L}$.

The determination of total reducing sugars was carried out by DNS-dinitrosalicylic acid method (Miller 1959), whereas lactose was determined by UV method at $365 \mathrm{~nm}$ using the Lactose/D-Galactose Enzymatic Analysis kit (R-Biopharm AG, Darmstadt, Germany).

The determination of fat was carried out according to Gerber's method (sensitivity 0.05\%). Skim milk butyrometers with narrowed scales were used and six samples of each powder were tested for error minimization (International Organization of Standardization 2008; ISO 2446:2008| IDF 226:2008).

The moisture content was determined by a MettlerToledo International Inc, Greifensee, Switzerland LJ16 

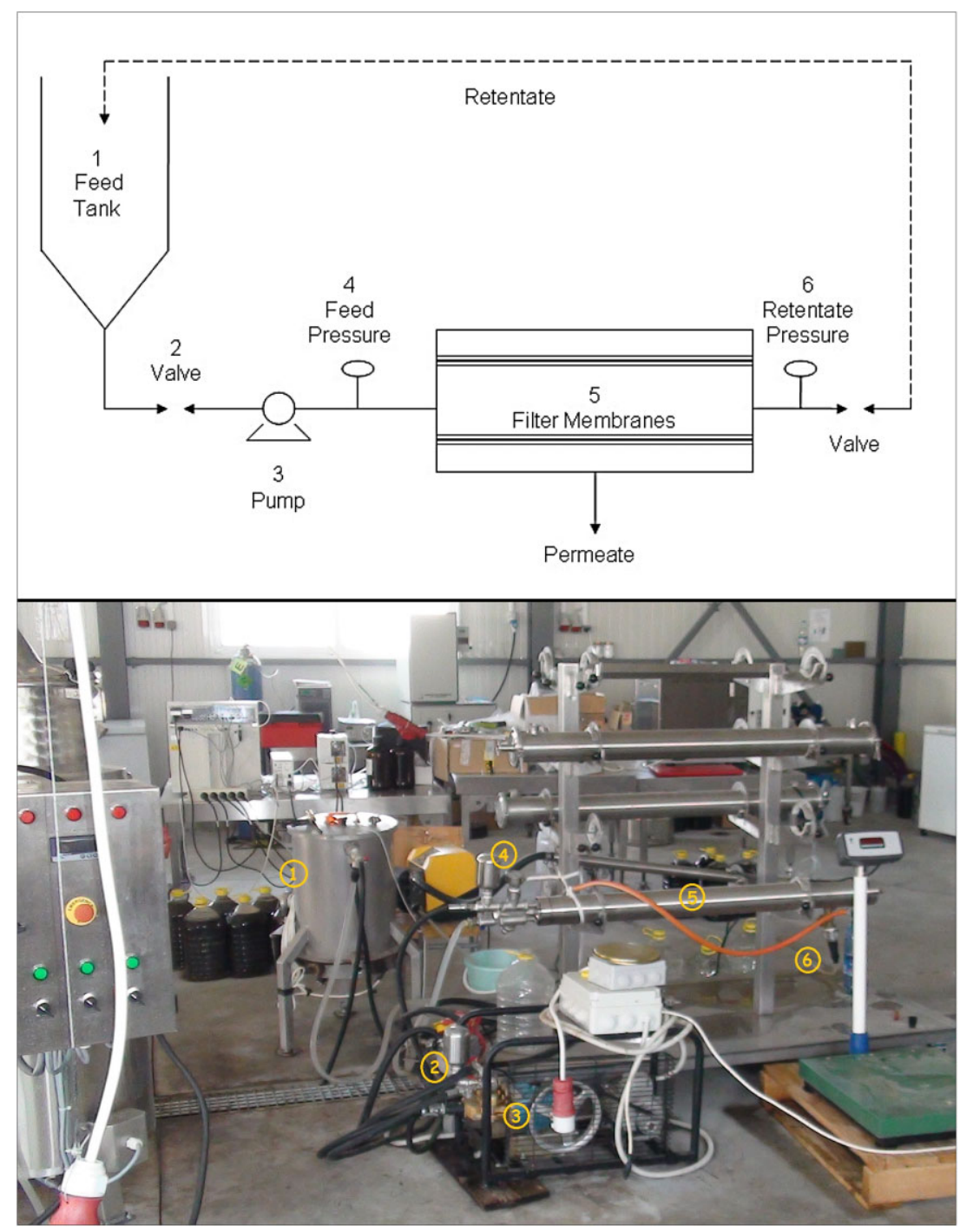

FIG. 1. PILOT SCALE

ULTRAFILTRATION/DIAFILTRATION PROCESS infrared moisture determination balance at $105 \mathrm{C}$ until constant weight was achieved ( $2 \mathrm{mg} / \mathrm{s})$.

Finally, mineral content was measured via the method of dry ash (International Dairy Federation 1964b; IDF 27:1964).

\section{Sensory Evaluation}

The sensory evaluation of the powder was based on texture and color differences between the produced powder and a standard whey powder, produced by direct drying (no UF/DF included). For both characteristics, a three-value scale was used. For color, the target value was the standard powder's white, with gray and green being the alternative two values to categorize the produced powder. In the case of texture, the target value was the fine powder texture of the standard powder, with the alternative two values being "big particles," which is also acceptable as it is not a defect, and "crystalloid," which is not an acceptable form.

\section{Experimental Process}

Unit Preparation/Maintenance. Before and after each process, a chemical cleaning procedure was performed to restore the flux and retention characteristics of the membrane and to prevent microbiological growth. For this reason, three steps (washes) were followed. During the first step, $40 \mathrm{~L}$ of water at a temperature of $48 \mathrm{C}$ was used along with $360 \mathrm{~g}$ of potassium hydroxide (Ecolab Inc, St. Paul, Minnesota, USA, P3 ultrasil 69), $160 \mathrm{~g}$ of subtilisin (Ecolab P3-67) and $40 \mathrm{~g}$ of amine oxide. For the second wash, $120 \mathrm{~g}$ of acidic liquid (a mixture of nitric and phosphoric acid, 
Ecolab P3-75) was added to $30 \mathrm{~L}$ of water $\left(48^{\circ} \mathrm{C}\right)$. At the last wash, $240 \mathrm{~g}$ of sodium hydroxide (Ecolab P3-110) was used along with $30 \mathrm{~L}$ of water.

For the maintenance of the membranes, $40 \mathrm{~g}$ of potassium metabisulfite in $40 \mathrm{~L}$ of water was used.

UF/DF Process. A first series of experiments was performed using the cylindrical membranes by measuring the permeate flux at different combinations of transmembrane pressures $(\Delta p)$ and applied temperature $(T)$. In particular, $\Delta p$ equal to 3,4 and 5 bar and $T$ equal to 20,30 and $40^{\circ} \mathrm{C}$ were tested.

The second series of experiments was performed with the spiral membrane and by measuring the permeate flux at a transmembrane pressure $\Delta p$ equal to 3 bar while two values of temperature were applied $\left(30\right.$ and $\left.40^{\circ} \mathrm{C}\right)$. Given the results of the first series of experiments, a smaller number of combinations $(\Delta p, T)$ was investigated. The main interest at this stage was the yield of whey into the two desired proteins, Lf and IgG, by using a membrane with a smaller MWCO.

Before starting each process, the UF/DF system was operated with just $50 \mathrm{~L}$ of tap water. Then, approximately $50 \mathrm{~L}$ of whey was placed into the tank and its temperature was adjusted to the desired $T$ value by the heat exchanger. The desired feed flow rate was adjusted by the main pump. The UF process was combined with DF steps as follows. Every $10 \mathrm{~min}$, the collected permeate was weighed and then replaced by adding tap water into the tank instead of deionized, which is usually used at DF. The use of nondeionized water was preferred in order to keep the process as simple as possible. This step was repeated until the membranes could not hold any more retentate (end of first RUN). The retentate was then collected from the membranes; it was diluted to the original volume (of the whey) and was placed again into the tank to repeat the same process (second RUN). These RUNS were repeated until a ratio of 5:1 was obtained between the volume of the original whey and the volume of the final retentate. At the end of the last run, the retentate was removed from the membranes, was weighed and finally stored at $-25^{\circ} \mathrm{C}$.

Drying. For the powder production, the obtained retentate was defrosted at room temperature and it was divided into two parts. The first part was freeze-dried at $-110^{\circ} \mathrm{C}$, whereas the second was spray-dried (input $T 130^{\circ} \mathrm{C}$, output $T 60^{\circ} \mathrm{C}$, aspirator at $100 \%$, flow $35 \%$ and pump set at $25 \%$ ). As mentioned, the level of drying was set according to the desired water activity $\left(a_{\mathrm{w}}\right)$ of the final powder (which should be at most 0.24 ). The powder were then vacuumpacked and stored at $4-8^{\circ} \mathrm{C}$.

\section{RESULTS AND DISCUSSION}

The produced whey powder were evaluated from both operational (i.e., $[\Delta p, T]$ combinations during UF/DF) and technological (i.e., drying method) points of view.

The key performance indicators to assess the powder obtained were defined as follows: (1) the permeate flux value $\mathrm{J}\left(\mathrm{kg} / \mathrm{m}^{2} \mathrm{~h}\right)$ during DF, as an indicator of the performance of the process; (2) the yield of retentate into powder (\% [g powder/g retentate]) to evaluate both drying methods; (3) the yield of whey into powder for both drying methods (\% [g powder/g whey]). This indicator was used for the evaluation of the overall process (UF/DF followed by drying); (4) sensory evaluation of the produced powder, color and texture; and (5) composition of the produced powder. As the resulting minor protein amounts (Lf, IgG) in the produced powder depend on (a) the initial amounts present in the whey sample and (b) the $\mathrm{UF} / \mathrm{DF}$ step in combination with the drying process selected, the yield of minor proteins in whey into minor proteins in powder is considered. On the one hand, the selectivity is evaluated via the yields of individual minor proteins originally present in whey into their resulting amount in powder (yield of Lf from whey into powder, and yield of IgG from whey into powder, respectively) (\% [g minor protein in powder/g minor protein in whey]). On the other hand, bioactivity of the produced powder is assessed via the amount of total minor proteins in the powder and via the total protein content in the powder. The resulting values for the key performance indicators are listed in Table 1. Although the main objective was the creation of whey powder with an increased content of certain minor (target) proteins ( $\mathrm{Lf}$ and $\mathrm{IgG}$ ), evaluation of the remaining substances present in the final product is also important. For example, an increased amount of lactose could be an indicator that there is room for further improvement of selectivity (suboptimal performance of the DF step). Also, an increased amount of salts or fat could create problems not only during the production itself but also during the storage and the analysis. Therefore, fat, moisture, mineral content, total sugar and lactose in particular were monitored in the final product (Table 2).

\section{First Set of Experiments: Cylindrical Membrane Tests}

Flux. Overall, the permeate flux values were satisfactory as any value exceeding $15 \mathrm{~kg} / \mathrm{m}^{2} \mathrm{~h}$ can be considered as commercially exploitable (Petrotos et al. 1998). Regarding the influence of transmembrane pressure on flux values, no clear trend was found, although for all conditions tested, the 
TABLE 1. EVALUATION FACTORS FOR THE PRODUCED POWDERS

\begin{tabular}{|c|c|c|c|c|c|c|c|c|c|}
\hline & $\begin{array}{l}\text { Average flux } \\
\left(\mathrm{kg} / \mathrm{m}^{2} \mathrm{~h}\right)\end{array}$ & $\begin{array}{l}\text { Fouling or } \\
\text { polarization }\end{array}$ & $\begin{array}{l}\text { Yield of } \\
\text { retentate } \\
\text { in powder (\%) }\end{array}$ & $\begin{array}{l}\text { Yield of } \\
\text { whey in } \\
\text { powder (\%) }\end{array}$ & Color & Texture & $\begin{array}{l}\text { Yield in } \\
\text { Lf (\%) }\end{array}$ & $\begin{array}{l}\text { Yield in } \\
\operatorname{lgG}(\%)\end{array}$ & $\begin{array}{l}\text { Yield in } \\
L F+\lg G(\%)\end{array}$ \\
\hline \multicolumn{10}{|l|}{ Cylindrical membranes } \\
\hline$\Delta p: 3$ bar $T: 20^{\circ} \mathrm{CSpray}$ dried & 35.19 & Y & 3.57 & 0.52 & White & $\mathrm{F}$ & 40.74 & 5.7 & 7.21 \\
\hline$\Delta p: 3$ bar $T: 30^{\circ} \mathrm{CFreeze}$ dried & 40.88 & Y & 11.80 & 0.80 & Green & C & 57.66 & 14.8 & 16.62 \\
\hline$\Delta p: 3$ bar $T: 30^{\circ} \mathrm{CSpray}$ dried & 40.88 & Y & 7.18 & 0.48 & Gray & $\mathrm{F}$ & 36.85 & 8.20 & 9.44 \\
\hline$\Delta p: 3$ bar $T: 40^{\circ} \mathrm{CFreeze}$ dried & 25.43 & $\mathrm{Y}$ & 3.60 & 1.29 & Gray & C & 40.99 & 23.55 & 24.31 \\
\hline$\Delta p: 4$ bar $T: 20^{\circ} \mathrm{CFreeze}$ dried & 30.75 & $\mathrm{~N}$ & 7.30 & 1.09 & White & $\mathrm{BP}$ & 78.61 & 23.41 & 25.81 \\
\hline$\Delta p: 4$ bar $T: 20^{\circ} \mathrm{CSpray}$ dried & 30.75 & $\mathrm{~N}$ & 4.49 & 0.67 & White & $\mathrm{F}$ & 53.24 & 14.55 & 16.22 \\
\hline$\Delta p: 4$ bar $T: 30^{\circ} \mathrm{CFreeze}$ dried & 32.07 & $\mathrm{~N}$ & 5.72 & 1.32 & White & $C$ & 82.25 & 15.03 & 17.94 \\
\hline$\Delta p: 4$ bar $T: 30^{\circ} \mathrm{C}$ Spray dried & 32.07 & $\mathrm{~N}$ & 1.91 & 0.44 & White & $\mathrm{F}$ & 34.50 & 5.99 & 7.22 \\
\hline$\Delta p: 4$ bar $T: 40^{\circ} \mathrm{CFreeze}$ dried & 29.40 & $\mathrm{~N}$ & 7.87 & 0.77 & Gray & C & 50.54 & 16.65 & 18.12 \\
\hline$\Delta p: 5$ bar $T: 20^{\circ} \mathrm{CSpray}$ dried & 43.18 & Y & 4.41 & 0.20 & White & $\mathrm{F}$ & 13.09 & 13.04 & 13.04 \\
\hline$\Delta p: 5$ bar $T: 40^{\circ} \mathrm{CFreeze}$ dried & 48.81 & Y & 8.00 & 0.74 & Green & C & 46.67 & 21.73 & 22.81 \\
\hline$\Delta p: 5$ bar $T: 40^{\circ} \mathrm{CSpray}$ dried & 48.81 & Y & 4.12 & 0.38 & Gray & $\mathrm{F}$ & 24.79 & 9.16 & 9.84 \\
\hline \multicolumn{10}{|l|}{ Spiral membrane } \\
\hline$\Delta p: 3$ bar $T: 30^{\circ} \mathrm{CFreeze}$ dried & 88.05 & Y & 5.76 & 0.70 & White & $\mathrm{BP}$ & 68.45 & 19.81 & 21.94 \\
\hline$\Delta p: 3$ bar $T: 30^{\circ} \mathrm{CSpray}$ dried & 88.05 & Y & 2.07 & 0.51 & White & $\mathrm{F}$ & 38.17 & 5.03 & 6.49 \\
\hline$\Delta p: 3$ bar $T: 40^{\circ} \mathrm{CFreeze}$ dried & 54.19 & Y & 4.56 & 0.57 & Green & $C$ & 58.15 & 22.36 & 23.93 \\
\hline$\Delta p: 3$ bar $T: 40^{\circ} \mathrm{CSpray}$ dried & 54.19 & Y & 2.00 & 0.50 & Gray & $\mathrm{F}$ & 29.23 & 7.71 & 8.65 \\
\hline
\end{tabular}

(1) Yield of retentate into powder (\% [g powder/g retentate]); (2) yield of whey into powder (\% [g powder/g whey]); (3) yield in Lf (\% [g Lf in powder/g Lf in whey]); (4) yield in IgG (\% [g IgG in powder/g IgG in whey]); (5) yield in Lf + IgG (\% [g Lf + IgG in powder/g Lf + IgG in whey]). BP, big particles; C, crystalloid; F, fine; IgG, immunoglobulin G; Lf, lactoferrin.

maximum flux occurred at the highest transmembrane pressure of 5 bar. This finding agrees with the results of Baldasso et al. (2011), who reported that flux increased with transmembrane pressure during concentration and purification of whey proteins by UF. It was also observed that only at the highest temperature value of $40^{\circ} \mathrm{C}$ the flux increased with the transmembrane pressure. Overall, however, for the influence of temperature on flux values, again, no clear trend could be detected. Increasing temperature, on the one hand, results in a decrease in the viscosity of the processed fluid, which reduces the resistance to flow and promotes turbulence and, on the other hand, also

TABLE 2. COMPOSITION OF THE PRODUCED POWDER

\begin{tabular}{|c|c|c|c|c|c|c|c|c|}
\hline & $\begin{array}{l}\text { Moisture } \\
(\%)\end{array}$ & $\operatorname{Lf}(\%)$ & $\lg G(\%)$ & $\begin{array}{l}\text { Total } \\
\text { protein (\%) }\end{array}$ & Fat (\%) & $\begin{array}{l}\text { Total } \\
\text { sugar (\%) }\end{array}$ & $\begin{array}{l}\text { Lactose } \\
(\%)\end{array}$ & Ash (\%) \\
\hline \multicolumn{9}{|l|}{ Cylindrical membranes } \\
\hline$\Delta p: 3$ bar $T: 20^{\circ} \mathrm{C}$ Spray dried & 6.78 & 2.35 & 7.25 & 69.7 & 20.5 & 1.0 & 0.4 & 2.0 \\
\hline$\Delta p: 3$ bar $T: 30^{\circ} \mathrm{C}$ Freeze dried & 5.81 & 2.18 & 12.35 & 73.2 & 16.0 & 3.0 & 2.2 & 1.8 \\
\hline$\Delta p: 3$ bar $T: 30^{\circ} \mathrm{C}$ Spray dried & 5.89 & 2.29 & 11.25 & 72.4 & 18.5 & 1.0 & 0.4 & 2.1 \\
\hline$\Delta p: 3$ bar $T: 40^{\circ} \mathrm{C}$ Freeze dried & 7.05 & 0.96 & 12.17 & 71.4 & 16.6 & 3.0 & 2.2 & 1.9 \\
\hline$\Delta p: 4$ bar $T: 20^{\circ} \mathrm{C}$ Freeze dried & 7.20 & 2.17 & 14.26 & 67.9 & 19.9 & 3.0 & 2.2 & 1.9 \\
\hline$\Delta p: 4$ bar $T: 20^{\circ} \mathrm{C}$ Spray dried & 5.49 & 2.39 & 14.41 & 70.6 & 20.7 & 1.0 & 0.4 & 2.1 \\
\hline$\Delta p: 4$ bar $T: 30^{\circ} \mathrm{C}$ Freeze dried & 7.04 & 1.88 & 7.58 & 68.5 & 19.5 & 3.0 & 2.2 & 1.8 \\
\hline$\Delta p: 4$ bar $T: 30^{\circ} \mathrm{C}$ Spray dried & 7.01 & 2.36 & 9.04 & 69.5 & 20.5 & 1.0 & 0.4 & 1.9 \\
\hline$\Delta p: 4$ bar $T: 40^{\circ} \mathrm{C}$ Freeze dried & 5.01 & 1.97 & 14.32 & 69.9 & 20.0 & 3.0 & 2.2 & 1.9 \\
\hline$\Delta p: 5$ bar $T: 20^{\circ} \mathrm{C}$ Spray dried & 6.90 & 0.66 & 14.29 & 70.5 & 19.6 & 1.0 & 0.4 & 1.7 \\
\hline$\Delta p: 5$ bar $T: 40^{\circ} \mathrm{C}$ Freeze dried & 4.91 & 1.90 & 19.52 & 71.6 & 18.5 & 3.0 & 2.2 & 1.7 \\
\hline$\Delta p: 5$ bar $T: 40^{\circ} \mathrm{C}$ Spray dried & 6.81 & 1.96 & 15.99 & 70.2 & 20.0 & 1.0 & 0.4 & 1.6 \\
\hline \multicolumn{9}{|l|}{ Spiral membrane } \\
\hline$\Delta p: 3$ bar $T: 30^{\circ} \mathrm{C}$ Freeze dried & 5.00 & 2.49 & 9.39 & 58.5 & 31.9 & 3.0 & 2.2 & 1.5 \\
\hline$\Delta p: 3$ bar $T: 30^{\circ} \mathrm{C}$ Spray dried & 5.08 & 2.31 & 6.64 & 57.8 & 31.9 & 1.0 & 0.4 & 3.5 \\
\hline$\Delta p: 3$ bar $T: 40^{\circ} \mathrm{C}$ Freeze dried & 5.90 & 1.57 & 13.02 & 60.3 & 29.8 & 3.0 & 2.2 & 1.0 \\
\hline$\Delta p: 3$ bar $T: 40^{\circ} \mathrm{C}$ Spray dried & 6.08 & 1.78 & 10.23 & 59.5 & 30.8 & 1.0 & 0.4 & 2.6 \\
\hline
\end{tabular}

IgG, immunoglobulin G; Lf, lactoferrin. 


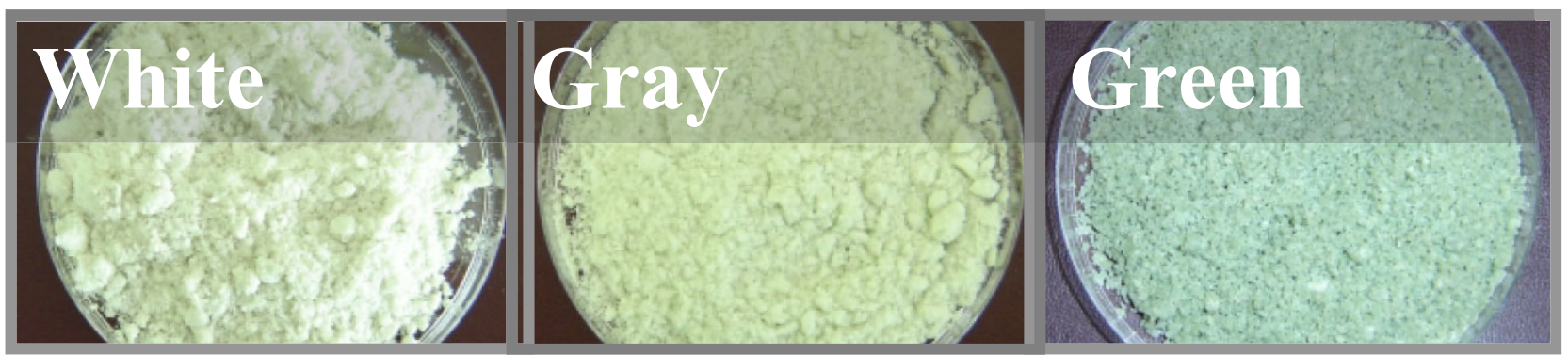

FIG. 2. COLOR CHANGE OF THE WHEY POWDER CAUSED BY INCREASED T DURING ULTRAFILTRATION/DIAFILTRATION

increases diffusivity and hence the rate of transport of solutes carried away from the membrane surface back into the bulk stream. Increasing temperature should therefore result in higher flux; however, for certain feeds, also a decrease in flux could be observed due to decreased solubility of feed components at higher temperatures or changes in fouling properties.

Yield of Retentate into Powder by Freeze Drying and Spray Drying. A general observation is that freeze drying resulted in a much higher yield of retentate into powder (mean value 8.20 , SD 2.58) as compared to spray drying (mean value 4.43, SD 2.16). For the calculation of the mean value of the yield of retentate into powder (both freeze- and spray-dried), data were used only from experiments that resulted in both freeze-dried and spray-dried powder. This difference was found to be statistically significant when performing a Student's paired $t$-test: mean difference value 3.78 , SD $0.74, n=4 ; t(3)=10.17$, $t \_$crit $=3.18$, two-tailed $P=0.002$ (95\% confidence level). This observation could be explained by the composition differences between the produced powder, which will be discussed later.

\section{Yield of Whey into Whey Powder by Freeze Drying} and Spray Drying. From a technological point of view, freeze drying resulted in a (much) higher yield than spray drying at all combinations of $(\Delta p, T)$ tested. From an operational point of view, the highest yield for freeze drying (yield equal to $1.32 \%)$ was obtained at $(\Delta p=4$ bar, $T=30^{\circ} \mathrm{C}$ ); for spray drying, the optimal combination $\left(\Delta p=4\right.$ bar, $T=20^{\circ} \mathrm{C}$ ) resulted in a yield equal to $0.67 \%$.

Sensory Evaluation. It is observed that both color and texture of the resulting powder were independent of the transmembrane pressure $\Delta p$ applied. Temperature $T$ had an influence on color and texture, although more pronounced for freeze drying than for spray drying.

For freeze drying, an increase of $T$ resulted in a color shift from white over gray to green powder (see Fig. 2). The gray or green can be explained by protein or lipid denaturation in combination with the presence of iron and copper from the equipment. Also, the texture became more crystalloid at higher values of temperature $T$. For the spray-dried powder, the increase of $T$ had a similar but less intense effect on color, whereas no significant effect on powder texture was observed. The crystallization of the powder is strongly related to the remaining lactose. Lactose, which is amorphous and hygroscopic, crystallizes to nonhygroscopic $\alpha$-lactose monohydrate when it is cooled (Tunick 2008). A rich crystallization is achieved by concentrating the whey to a high level of solids content and by cooling the concentrate. Thus, it was expected that freeze-dried powder would have more crystalloid texture than the spray dried ones, which were produced at higher temperature and maintain a larger amount of moisture.

Whey Powder Composition: Proteins. From a technological point of view, it was observed that freeze drying consistently resulted in higher yield values as compared to spray drying, for both Lf and IgG. The temperature applied during spray drying is much higher as compared to freeze drying, and even though it is applied for only a limited time, it has an effect on the heat-sensitive whey proteins. As for the operational conditions, the highest yield of Lf in freeze-dried powder was achieved at temperature $T$ equal to $30 \mathrm{C}$ (for all transmembrane pressures), whereas for IgG, no clear trend could be observed over the examined $(\Delta p, T)$ combinations. Also, the largest amount of total proteins was found in the freeze-dried powder produced at $T$ equal to $30 \mathrm{C}$ and lower $\Delta p$ values during the UF/DF. Representative chromatographs of both freeze-dried and spray-dried powder are presented in Fig. 3. A small difference in the elution of the Lf peak was noted between freeze-dried and spray-dried powder, whereas no alteration was observed during the determination of $\operatorname{IgG}$.

Whey Powder Composition: Other Substances. The following additional observations were made for the remaining components in the produced powder. As 

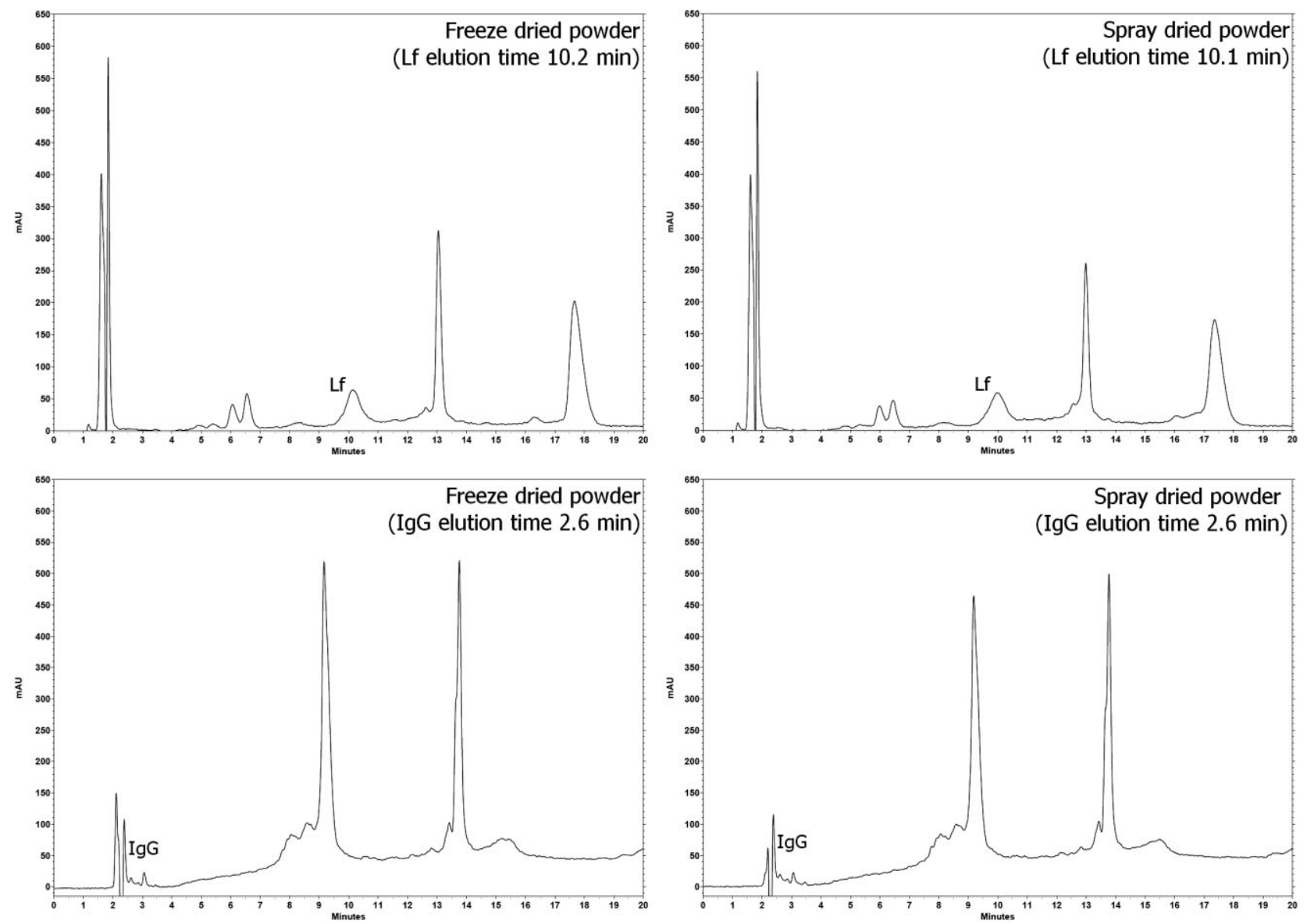

FIG. 3. CHROMATOGRAPHS OF FREEZE- AND SPRAY-DRIED POWDER FOR THE DETERMINATION OF LACTOFERRIN (Lf) AND IMMUNOGLOBULIN G $(\lg G)$

expected, the amount of fat was higher (in one case equal) in spray-dried powder versus freeze-dried powder and increased with temperature. This is related to the more mild process of spray drying when compared to freeze drying. Also, moisture content followed an increasing trend with the temperature, but no consistent trend for spray-dried powder versus freeze-dried powder was found. On the contrary, total sugar content and lactose content in particular were higher in the freeze-dried powder and were independent of the applied $(\Delta p, T)$ combination. Finally, the mineral content (ash) was independent of both the drying method and the applied $(\Delta p, T)$ combination.

\section{Second Set of Experiments: Spiral Membrane Tests}

Flux. At this second series of tests, the average fluxes were much higher than in the previous experiment. In both cases
( $T$ : $30^{\circ} \mathrm{C}$ and $40^{\circ} \mathrm{C}$ ), the flux values were particularly high $\left(88.05\right.$ and $54.19 \mathrm{~kg} / \mathrm{m}^{2} \mathrm{~h}$, respectively) and again commercially exploitable. According to Lin's observation, the larger the pore size of membrane, the more easily organic matter enters inside the membrane pores, resulting in more serious fouling thus leading to lower flux (Lin et al. 1999). This could be the reason why the cylindrical membranes gave lower flux values, although these have a higher cut-off. Moreover, with the use of the spiral membrane, a larger turbulence of the whey was achieved, resulting in less serious fouling. The average flux at $30^{\circ} \mathrm{C}$ was much higher $(62.5 \%)$ than the average flux at $40^{\circ} \mathrm{C}$. The duration of each run and the total duration of the overall process were also shorter at the lower $T$ value, which justifies the larger values of flux at $30^{\circ} \mathrm{C}$ with shorter duration: any process becomes less capable of delivering the desired product specifications after long hours of operation when long-term fouling becomes more significant (Yee et al. 2007; Sprinchan 2009). At temperature $T$ equal to $40 \mathrm{C}$, the flux had a decreasing trend, 
indicating membrane polarization or fouling, whereas at $30^{\circ} \mathrm{C}$, a (slowly) decreasing trend was observed only after the third run.

Yield of Retentate into Powder by Freeze Drying and Spray Drying. At both temperature values, the freeze drying method resulted in a higher yield in powder (mean value 5.17, SD 0.70) as compared to the spray drying method (mean value 2.04, SD 0.01). (The number of experimental conditions [and thus data points] was too small to perform a reliable Student's paired $t$-test.)

Yield of Whey into Whey Powder by Freeze Drying and Spray Drying. The yields of whey into freeze-dried powder were larger than the yields of whey into spraydried powder, at both $T$ values. From an operational point of view, larger yields were obtained at the lowest temperature.

A two-factor variance analysis without replication was performed to evaluate (1) whether the yields of whey into powder are significantly different between the two drying methods, and (2) whether the temperature $T$ applied during UF/DF significantly influences the yield of whey into powder. The statistical analysis pointed out that in both cases, no significant influence was found (95\% confidence level).

Sensory Evaluation. Both the freeze-dried and the spray-dried powders produced at $30^{\circ} \mathrm{C}$ had a nice white color and a noncrystalloid texture. When $T$ was increased to $40 \mathrm{C}$, the color of the spray-dried powder turned into gray, whereas the freeze-dried powder got an even darker green. In the case of freeze drying, there was also a degradation of the texture.

Whey Powder Composition: Proteins. From a technological point of view, the drying method had a pronounced effect on both the Lf and the IgG yield values: freeze drying always resulted in higher yields than spray drying. Similarly, the largest amount of total proteins was found in the freeze-dried powder. As for the operational conditions, the Lf yield values decreased with temperature, whereas the IgG yield values increased. Also, the total protein amount increased with temperature.

Whey Powder Composition: Other Substances. The influence of the applied temperature $T$ during the UF/DF step was also obvious for the remaining components in the produced powders. At lower temperature, larger amounts of fat and ash were achieved, whereas at higher temperature, the amount of moisture was higher. Finally, total sugar content and lactose content in particular were not influenced by the applied temperature.

\section{Optimum Conditions for Production of Whey Powder Enriched in Lf and IgG}

During the two sets of experiments (corresponding to two types of membranes), 16 powder were produced using two drying technologies and a variety of operational settings for $(\Delta p, T)$ applied during UF/DF. In order to define the optimum combination of (technological and operational) factors for the production of a whey powder enriched in Lf and IgG, the following criteria were used.

First, the best performance of the UF/DF process: this criterion encompasses three parameters, namely the value of the average flux, the appearance or not of fouling or concentration polarization, and the yield of whey into powder.

Second, the yield of minor proteins in whey into minor proteins in powder (and this for $\mathrm{Lf}, \operatorname{IgG}$ and $\mathrm{Lf}+\mathrm{IgG}$ ), in combination with the total protein content in the produced powder: this is the most important criterion as it indicates the efficiency of the process with respect to selectivity. It is also important for the commercial exploitation of the optimum method.

Finally, the sensory characteristics of the powder, including color and texture: this criterion is important for the acceptance of the powder not only as commercial products but also as indicator of the overall performance of the production process.

On the basis of these criteria, it is concluded that the highest yield in $(\mathrm{Lf}+\mathrm{IgG})$ was realized using cylindrical membranes at the operational conditions $(\Delta p=4$ bar, $T=20^{\circ} \mathrm{C}$ ) and when freeze drying was used. In addition, the produced powder had excellent sensory characteristics, a clear white color and rough but not crystalloid texture. During this test, no fouling or concentration polarization was observed. The flux value is satisfactory as it is commercially exploitable, whereas the yield of whey into powder is among the highest.

\section{CONCLUSIONS}

In this paper, the production of whey powder enriched in the bioactive proteins Lf and immunoglobulins from feta cheese whey was investigated using UF combined with continuous variable volume DF. The influence of the applied transmembrane pressure and temperature during the UF/DF process on the average flux, on the powder yield, on the protein yield and on the sensory characteristics of the final powder was assessed. 


\section{Influence of Transmembrane Pressure}

With respect to the UF/DF process, the highest average flux value was observed when the $75-\mathrm{kDa}$ spiral membrane was used. In the case of the $100-\mathrm{kDa}$ cylindrical membrane set-up, the maximum average flux was achieved at the highest transmembrane pressure tested. In both series of experiments, a decreasing trend of the (quite high) flux values was observed throughout the DF step, reflecting the appearance of concentration polarization and/or fouling, particularly at the highest transmembrane pressure of 5 bar (cylindrical membrane set-up). Higher flux values did not correlate with higher yield values of whey into powder nor into proteins (neither total proteins nor the examined bioactive proteins). No clear correlation could be detected between the applied transmembrane pressure and the sensory characteristics of the final powder.

\section{Influence of Temperature}

At any given transmembrane pressure, a temperature equal to $30^{\circ} \mathrm{C}$ had the most positive impact on flux in both experiments. An increase of temperature from 30 to $40^{\circ} \mathrm{C}$ resulted in higher values for yield of whey in powder and in immunoglobulins but lower values of yield in the temperature-sensitive Lf. The sensory characteristics were mostly affected by temperature rise. At higher temperature values, a gray to green color was observed in the retentate and (more clearly) in the powder.

\section{Influence of Drying Method}

For freeze drying, the yields in powder, in lactoferrin and in immunoglobulins were significantly higher. For color and texture, spray-dried powder were more acceptable as any color alteration was less intense and the texture was always uniform. The drying method had a direct impact on the composition of the final products. Freeze-dried powder contained less moisture and fat but more sugars, whereas spray-dried powder had higher mineral content.

Overall, the experiments described in this paper resulted in exploitable conclusions for the feta cheese whey utilization. Whey powder were produced with Lf content up to $2.5 \%$ and $\operatorname{IgG}$ content up to $14.4 \%$, and with excellent sensory characteristics. The freeze-dried powder, which was produced by UF combined with continuous variable volume DF using a set of 18 PVDF cylindrical membranes with an MWCO 100,000 Da at an applied pressure of 4 bar and at temperature of $20^{\circ} \mathrm{C}$, appeared to be the most advantageous according to the set criteria. At these optimum conditions, freeze-dried powder with $2.2 \%$ Lf content and $14.3 \%$ IgG content (total content of the two bioactive proteins $16.4 \%$ ) were produced, and at the same time, the highest yield in ( $\mathrm{Lf}+\mathrm{IgG}$ ) (equal to $25.8 \%$ ) was realized [individual yields equal to $78.6 \%$ for $\mathrm{Lf}$ and $23.4 \%$ for $\mathrm{IgG}$ ]. In addition, the produced powder had excellent sensory characteristics, a clear white color and rough but not crystalloid texture. During this test, no fouling or concentration polarization was observed. The flux value is satisfactory as it is commercially exploitable, whereas the yield of whey into powder is among the highest.

\section{ACKNOWLEDGMENTS}

This work was supported by project PFV/10/002 (Center of Excellence OPTEC - Optimization in Engineering) of the KU Leuven Research Council, projects G.0930.13 and KAN2013 1.3.189.13 of the Fund for Scientific ResearchFlanders, and the Belgian Program on Interuniversity Poles of Attraction initiated by the Belgian Federal Science Policy Office. J. Van Impe holds the chair Safety Engineering sponsored by the Belgian Chemistry and Life Sciences Federation Essenscia.

\section{REFERENCES}

ATRA, R., VATAI, G., BEKASSY-MOLNA, E. and BALIT, A. 2005. Investigation of ultra- and nanofiltration for utilization of whey protein and lactose. J. Food Eng. 67, 325-332.

BALDASSO, C., BARROS, T.C. and TESSARO, I.C. 2011. Concentration and purification of whey proteins by ultrafiltration. Desalination 278, 381-386.

BOTTOMLEY, R.C. 1993. Isolation of an immunoglobulin rich fraction from whey. U.S. Patent No. 5008376.

CHEN, J.P. and WANG, C.H. 1991. Microfiltration affinity purification of lactoferrin and immunoglobulin $\mathrm{G}$ from cheese whey. J. Food Sci. 563, 701-706.

CLARE, D.A., CATIGNANI, G.L. and SWAISGOOD, H.E. 2003. Biodefense properties of milk: The role of antimicrobial proteins and peptides. Curr. Pharm. Des. 916, 1239-1255.

DA COSTA, A.R., FANE, A.G. and WILEY, D.E. 1993. Ultrafiltration of whey protein solutions in spacer-filled flat channels. J. Memb. Sci. 76, 245-254.

DE WIT, J.N. 1998. Nutritional and functional characteristics of whey proteins in food products. J. Dairy Sci. 81, 597-608.

ELGAR, D.F., NORRIS, C.S., AYERS, J.S., PRITCHARD, M., OTTER, D.E. and PALMANO, K.P. 2000. Simultaneous separation and quantification of the major bovine whey proteins including proteose peptone and caseinomacropeptide by reversed-phase high performance liquid chromatography on polystyrene-divinylbenzene. J. Chromatogr. A 878, 183-196.

FOEGEDING, E.A. and LUCK, P.J. 2002. Milk proteins: Whey protein products. In Encyclopedia of Dairy Sciences (J. Roginski, J.W. Fuquay and P.F. Fox, eds.) pp. 1957-1960, Academic Press, London, U.K. 
GARCIA-GARIBAY, M., JIMENEZ-GUZMAN, J. and HERNANDEZ-SANCHEZ, H. 2008. Whey bioengineering and health. In Food Engineering: Integrated Approaches (G.F. Gultierrez-Lopez, G.V. Barbarosa-Canovas, J. Welti-Chanes and E. Parad-Aries, eds.) pp. 415-431, Springer, New York.

GILL, H.S. and CROSS, M.L. 2000. Anticancer properties of bovine milk. Br. J. Nutr. 84, 5161-5166.

HALL, W.L., MILLWARD, D.J., LON, S.J. and MORGAN, L.M. 2003. Casein and whey exert different effects on plasma amino acid profiles, gastrointestinal hormone secretion and appetite. Br. J. Nutr. 892, 239-248.

HOLT, C., MCPHAIL, D., NEVISON, I., NYLANDER, T., OTTE, J., IPSEN, R.I., BAUER, R., OGENGAL, L., OLIEMAN, K., de KRUIF, K.G., et al. 1999. Apparent chemical composition of nine commercial or semi-commercial whey protein concentrates, isolates and fractions. Int. J. Food Sci. Technol. 34, 543-556.

HUFFMAN, L.M. 1996. Processing whey protein for use as food ingredient. Food Technol. 50, 49-52.

INTERNATIONAL DAIRY FEDERATION. 1964a.

Determination of the protein content of processed cheese products. FIL-IDF 25:1964. International Dairy Federation, Brussels.

INTERNATIONAL DAIRY FEDERATION. 1964b.

Determination of the ash content of processed cheese products. FIL-IDF 27:1964. International Dairy Federation, Brussels.

INTERNATIONAL ORGANIZATION OF STANDARDIZATION. 2008. Milk - determination of fat content. ISO 2446:2008 (IDF 226:2008). International Organization of Standardization, Geneva.

KINGHORN, N.M., NORRIS, C.S., PATERSON, G.R. and OTTER, D.E. 1995. Comparison of capillary electrophoresis with traditional methods to analyze bovine whey proteins. J. Chromatogr., A 700, 111-123.

LIN, C.F., HUANG, Y.J. and HAO, O.J. 1999. Ultrafiltration process for removing humic substances: Effect of molecular weight fractions and PAC treatment. Water Res. 33, 1252-1264.

MARSHALL, K.R. 1982. Industrial isolation of milk proteins: Whey proteins. In Developments in Dairy Chemistry, Vol. 1 (P.F. Fox, ed.) pp. 339-373, Applied Science Publishers, London, U.K.

MILLER, G.L. 1959. Use of dinitrosalicylic acid reagent for determination of reducing sugar. Anal. Chem. 313, 426-428.
MOATSOU, G., HATZINAKI, A., KANDARAKIS, I. and ANIFANTAKIS, E. 2003. Nitrogenous fractions during the manufacture of whey protein concentrates from Feta cheese whey. Food Chem. 81, 209-217.

MORR, C.V. 1985. Composition, physicochemical and functional properties of reference whey protein concentrates. J. Food Sci. 50, 1406-1411.

PARODI, P.W. 1998. A role for milk proteins in cancer prevention. Aust. J. Dairy Technol. 53, 37-47.

PETROTOS, K.B., QUANTICK, P. and PETROPAKIS, H. 1998. A study of the direct osmotic concentration of tomato juice in tubular membrane - module configuration. I. The effect of certain basic process parameters on the process performance. J. Memb. Sci. 150, 99-110.

PLATE, K., BEUTEL, S. and BUCHHOLZ, H., DEMMER, W., FRÜHHOLZ, S.F., REIF, O., ULBER, R. and SCHEPER, T. 2006. Isolation of bovine lactoferrin, lactoperoxidase and enzymatically prepared lactoferricin from proteolytic digestion of bovine lactoferrin using adsorptive membrane chromatography. J. Chromatogr. A. 1117, 81-86.

SCOTT, G.H. and LUCAS, D.O. 1989. Immunologically active whey fraction and recovery process. U.S. Patent No. 4834874.

SPRINCHAN, E.G. 2009. Optimisation of technological regimes for obtaining protein-mineral concentrated products from secondary milk raw materials. Surf. Eng. Appl. Electrochem. 45, 63-70.

TSAKALI, E., PETROTOS, K., CHATZILAZAROU, A., STAMATOPOULOS, K., D’ALESSANDRO, A.G., GOULAS, P., MASSOURAS, T. and VAN IMPE, J.F.M. 2014. Determination of lactoferrin in feta cheese whey with RP-HPLC. J. Dairy Sci. 97, 4832-4837.

TUNICK, M.H. 2008. Whey protein production and utilization: A brief history. In Whey Processing, Functionality and Health Benefits (C.I. Onwulata and P.J. Huth, eds.) pp. 1-13, John Wiley \& Sons Inc. Publishing, Ames, IA.

VINCENZETTI, S., POLIDORI, P., MARIANI, P. and VITA, A. 2008. Protein fraction characterization of sheep milk from the Comisana breed. Vet. Res. Commun. 32, 179-181.

YEE, K.W.K., WILEY, D.E. and BAO, J. 2007. Whey protein concentrate production by continuous ultrafiltration: Operability under constant operating condition. J. Memb. Sci. 209, 125-137.

ZYDNEY, A.L. 1998. Protein separation using membrane filtration: New opportunities for whey fractionation. Int. Dairy J. 8, 243-250. 